\title{
Fungsi Badan Pertanahan Nasional Dalam Pengawasan Pejabat Pembuat Akta Tanah Di Kabupaten Tanjung Jabung Barat
}

\author{
Masriyani $^{1}$ \\ Fakultas Hukum, Universitas Batanghari, \\ Jalan Slamet Riyadi Broni Kota Jambi (0741) 65351 \\ imasyani77@gmail.com
}

\begin{abstract}
Abstrak
Dalam Peraturan Kepala Badan Pertanahan Nasional No. 1 Tahun 2006 sebagaimana telah diubah dengan Peraturan Kepala BPN nomor 23 tahun 2009 tentang ketentuan pelaksanaan Peraturan Pemerintah Nomor 37 Tahun 1998, Kepala Kantor Pertanahan melakukan pembinaan dan pengawasan terhadap Pejabat Pembuat Akta Tanah (PPAT). Bertitik tolak pada dasar hukum tersebut dan melihat pada pembangunan serta kebutuhan akan tanah maka untuk keabsahan kepemilikan atas tanah, harus diterbutkan melalui sertifikat hak milik. Untuk itu diperlukan pengawasan terhadap PPAT selaku pejabat yang berwenang dalam pembuatak Akta Tanah tersebut. Adapun permasalahan dalam penelitian ini adalah bagaimanakah Fungsi Badan Pertanahan Nasional Dalam Pembinaan dan Pengawasan Pejabat Pembuat Akta Tanah di wilayah Tanjung Jabung Barat. Tipe penelitian yang di gunakan adalah penelitian empiris. Data yang di gunakan adalah data primer dan data skunder. Pengumpulan data dilakukan melalui penelitian kepustakaan dan penelitian lapangan. Hasil penelitian menjelaskan tentang pembinaan dan pengawasan yang di lakukan Kepala Kantor Pertanahan terhadap tugas PPAT di Kabupaten Tanjung Jabung Barat, berjalan sebagaimana mestinya sesuai dengan Pasal 65 tentang Peraturan Kepala BPN Republik Indonesia No. 1 Tahun 2006 Tentang Ketentuan Pelaksanaan PP No. 37 Tahun 1998 Tentang Peraturan Jabatan PPAT dalam pembinaan dan pengawasan cukup optimal. Hal ini dapat terlihat bahwa untuk tahun 2016 sampai tahun 2017 pelanggaran yang dilakukan PPAT menurun. Pengawasan terhadap PPAT yang dilakukan oleh Kepala Kantor Pertanahan adalah dengan memberikan arahan pada semua pemangku kepentingan yang berkaitan dengan ke-PPAT-an, melakukan pengawasan atas organisasi profesi PPAT agar tetap berjalan sesuai dengan arah dan tujuannya, menjalankan tindakan-tindakan lain yang dianggap perlu untuk memastikan pelayanan PPAT tetap berjalan sebagaimana mestinya dan melakukan pengawasan terhadap PPAT dan PPAT sementara dalam rangka menjalankan kode etik profesi PPAT, Kantor Pertanahan Tanjung Jabung Barat bekerjasama dengan pihak terkait terutama IPPAT dan pengawas kode etik PPAT.

Kata kunci: pengawasan, badan pertanahan nasional
\end{abstract}

\begin{abstract}
In the national land Agency Chief Regulation No.1 Year 2006 as modified by regulation the head of BPN number 23-year 2009 on implementation of the provisions of the Government Regulation Number 37 Year 1998, head of the Office of land do coaching and surveillance against a land deed official (PPAT). Starting on the dotted the legal basis and see the development as well as the needs
\end{abstract}

${ }^{1}$ Masriyani, SH., MH, Dosen Tetap Yayasan Pendidikan Jambi, Universitas Batanghari, Program Studi Ilmu Hukum. 
of the ground then for the validity of the ownership of the land, should be are published through the certificate of property rights. For it is necessary supervision against the authorized officials as a PPAT in the deed of the land pembuatak. As for the problems in this research is how the functions of the national land Agency in the construction and supervision of land deed official Tanjung Jabung Barat region. The type of research that is in use is the empirical research. Data on use is the primary data and the data of skunder. Data collection was done through the research library and field research. The research describes the construction and supervision on Land against the head of the Office to do the task in Tanjung Jabung PPAT West, running as it should be in accordance with article 65 of the regulation of the Republic of Indonesia head of $B P N$ No. 1 year 2006 regarding the implementation of the provisions of REGULATION No. 37 Year 1998 Of Regulations Office of the PPAT in coaching and supervision is quite optimal. It can be seen that for the year 2016 year 2017 until the violations perpetrated PPAT decreased. Surveillance against PPAT performed by the Head Office of land is to provide direction to all stakeholders associated with the PPAT's, conducting surveillance over the organisation of the profession of PPAT to keep running in accordance with the direction and the goal, run other actions deemed necessary to ensure the service of PPAT continue to run properly and to conduct surveillance against a PPAT and PPAT in order to run the code of ethics of the profession, the PPAT Tanjung Jabung West land in cooperation with the relevant parties especially the IPPAT code of ethics watchdogs and PPAT.

Keywords: supervision, national land agency

\section{PENDAHULUAN}

Salah satu tujuan negara Indonesia sebagaimana tercantum dalam Undang Undang Dasar Republik Indonesia 1945 adalah untuk memajukan kesejahteraan umum, hal ini lebih ditegaskan lagi dalam Pasal 33 ayat (3) yang menggariskan kebijakan dasar mengenai penguasaan dan penggunaan sumber-sumber daya alam yang ada, yakni "Bumi dan air dan kekayaan alam yang terkandung di dalamnya dikuasai oleh Negara, dan dipergunakan untuk sebesar-besar kemakmuran rakyat."

Tanah merupakan karunia Tuhan Yang Maha Esa yang tidak dapat dipisahkan dari tata kehidupan makhluk hidup, oleh karena itu tanah mempunyai fungsi yang sangat penting bagi kehidupan manusia. Setiap manusia memerlukan tanah sebagai tempat tinggalnya maupun untuk mencari nafkah bagi kelangsungan hidupnya. Hubungan manusia dengan tanah merupakan hubungan yang sangat erat dan bersifat abadi, dimulai sejak manusia lahir hingga akhir hayatnya manusia selalu berhubungan dengan tanah.

Kebutuhan akan tanah dari hari ke hari semakin meningkat, antara lain disebabkan oleh meningkatnya jumlah penduduk dan kegiatan pembangunan, sedangkan luas tanah terbatas atau tetap. Dengan meningkatnya pembangunan di segala bidang, dan adanya tuntutan akan adanya mutu kehidupan yang lebih baik sebagai dampak positif dari keberhasilan pembangunan yang sedang dilaksanakan, semuanya ini memerlukan tanah sebagai sarana dasarnya. Sejalan dengan semakin meningkatnya kebutuhan akan tanah tersebut, sebagai konsekuensi logisnya maka telah meningkat pula berbagai masalah pertanahan 
yang dalam beberapa tahun terakhir ini muncul ke permukaan dan menjadi pusat perhatian masyarakat luas.

Masyarakat masih beranggapan bahwa pelayanan di bidang pertanahan masih terlalu sulit dan berbelit-belit dalam prosedur, lamanya waktu pemrosesan serta biaya yang tinggi. Penyebabnya bisa dikarenakan pelayanan kantor pertanahan yang kurang optimal. Hal ini menunjukkan adanya tuntutan masyarakat akan perlunya keterbukaan dalam pelaksanaan tugas, prosedur pembayaran yang sederhana, kepastian waktu dan biaya yang harus dibayar oleh masyarakat dalam penyelesaian urusan hak atas tanahnya, serta berbagai kemudahan dalam pelayanan maupun perlindungan hak-hak dan kepentingan masyarakat.

Dilandasi oleh amanat yang terkandung dalam pasal 33 ayat (3) UndangUndang Dasar Tahun 1945, sebagai kelanjutannya maka telah disusun UndangUndang Nomor 5 tahun 1960 tentang Peraturan Dasar Pokok-Pokok Agraria (UUPA) yang berarti bahwa telah diletakkan dasar yang kokoh bagi pelaksanaan pembangunan pertanahan guna terwujudnya tujuan pembinaan hukum pertanahan nasional dan menyelenggarakan administrasi pertanahan guna terwujudnya tujuan pembangunan nasional. Pasal 2 UUPA menjelaskan bahwa bumi (tanah), air dan ruang angkasa serta kekayaan alam yang terkandung di dalamnya yang terdapat di wilayah Republik Indonesia, bukan merupakan milik negara akan tetapi pada tingkatan tertinggi dikuasai oleh negara, sebagai organisasi kekuasaan seluruh rakyat yang memberi wewenang untuk mengatur dan menyelenggarakan peruntukan dan penggunaan, persediaan dan pemeliharaan bumi, air dan ruang angkasa tersebut, menentukan dan mengatur hubungan-hubungan hukum antara orang dengan bumi, air dan ruang angkasa yang dimaksud serta menentukan dan mengatur hubungan-hubungan hukum antara orang-orang dan perbuatan-perbutan hukum yang mengenai bumi, air dan ruang angkasa dalam wilayah Republik Indonesia.

Badan Pertanahan Nasional merupakan perpanjangan tangan pemerintah dalam pengaturan administrasi pertanahan, di Indonesia Badan Pertanahan Nasional mempunyai tugas melaksanakan tugas pemerintahan di bidang pertanahan secara nasional, regional dan sektoral. Salah satu tugas Badan Pertanahan Nasional menyelenggarakan fungsinya adalah "pengawasan dan pengendalian penguasaan pemilikan tanah.

Kedudukan Badan Pertanahan Nasional menjangkau sampai kedaerah pedesaan diseluruh wilayah Indonesia maka kegiatan dibidang Pertanahan akan dapat memberikan konstribusi konstruktif dalam pembangunan bangsa bila bentuk dan implementasi kegiatan dapat disinkronisasikan dengan kegiatan pemerintah daerah yang menjadi titik berat otonomi daerah salah satunya dalam memberikan pelayanan kepada masyarakat yang sering disebut dengan pelayanan publik. Pelayanan publik oleh aparatur pemerintah dewasa ini masih banyak dijumpai kelemahan sehingga belum dapat memenuhi kualitas yang diharapkan masyarakat.

Badan Pertanahan Nasional dalam melaksanakan fungsinya selaku pengawas terhadap pemilikan tanah menunjuk Pejabat Pembuat Akta Tanah (PPAT). Sesuai peraturan Kepala Badan Pertanahan Nasioanal Nomor 1 Tahun 2006 sebagaimana telah diubah dengan Peraturan Kepala BPN nomor 23 tahun 2009 tentang Ketentuan Pelaksanaan Peraturan Pemerintah Nomor 37 tahun 1998 tentang Peraturan Jabatan Pejabat Pembuat Akta Tanah, tugas pokok dari PPAT 
adalah melaksanakan sebagian kegiatan pendaftaran tanah dengan membuat akta sebagai bukti telah dilakukannya perbuatan hukum tertentu mengenai hak atas tanah atau Hak Milik Atas Satuan Rumah Susun yang akan dijadikan dasar bagi pendaftaran perubahan data pendaftaran tanah yang diakibatkan oleh perbuatan hukum itu, yang meliputi jual beli, tukar menukar, hibah, pemasukan ke dalam perusahaan (inbreng), pembagian hak bersama, pemberian Hak Guna Bangunan/ Hak Pakai atas tanah Hak Milik, pemberian Hak Tanggungan dan pemberian kuasa membebankan Hak Tanggungan.

Adapun yang menjadi rumusan masalah dalam tulisan ini adalah; "Bagaimanakah Fungsi Badan Pertanahan Nasional Kabupaten Tanjung Jabung Barat dalam Pengawasan terhadap Pejabat Pembuat Akta Tanah ?

\section{METODE PENELITIAN}

Metode Penelitian adalah cara melakukan sesuatu dengan menggunakan pikiran secara seksama untuk mencapai suatu tujuan dengan cara mencari, mencatat, merumuskan, dan menganalisis sampai menyusun laporan. Istilah metodologi berasal dari kata metode yang berarti jalan, namun demikian, menurut kebiasaan metode dirumuskan dengan kemungkinan-kemungkinan suatu tipe yang dipergunakan dalam penelitian dan penilaian. ${ }^{2}$

Penelitian ini menggunakan jenis penelitian empiris, sebab dari judul yang penulis angkat mengenai fungsi dari Badan Pertanahan Nasional terkait jalannya pengawasan terhadap Pejabat Pembuat Akta Tanah di Kabupaten Tanjung Jabung Barat. Penulis mendapatkan data dengan cara wawancara langsung untuk perolehan data yang akurat dan otentik.

\section{HASIL DAN PEMBAHASAN}

\section{Tinjauan Umum Pengawasan}

Kata "Pengawasan" berasal dari kata "awas" berarti "penjagaan".Istilah pengawasan dikenal dalam ilmu manajemen dengan ilmu administrasiyaitu sebagai salah satu unsur dalam kegiatan pengelolaan. George R Terry berpendapat bahwa istilah "control" sebagaimana dikutip Muchsan, artinya :"control is to determine what is accomplished, evaluate it, and applycorrective measures, if needed to ensure result in keeping with the plan"(Pengawasan adalah menentukan apa yang telah dicapai, mengevaluasi danmenerapkan tindakan korektif, jika perlu memastikan sesuai dengan rencana) $)^{3}$.

Sedangkan Muchsan berpendapat bahwa:

Pengawasan adalah kegiatan untuk menilai suatu pelaksanaan tugas secara defacto, sedangkan tujuan pengawasan hanya terbatas pada pencocokkan apakahkegiatan yang dilaksanakan telah sesuai dengan tolok ukur yang telahditetapkan sebelumnya (dalam hal ini berwujud suatu rencana/plan) ${ }^{4}$

${ }^{2}$ Soerjono Soekanto, Pengantar Penelitian Hukum, Universitas Indonesia Press, Jakarta, 2012, hlm. 5

${ }^{3}$ George Terry sebagaimana dikutip Muchsan dalam Siswanto Sunarno, 2005, hlm. 97

${ }^{4}$ A.P. Parlindungan, Pendaftaran Tanah di Indonesia (Berdasarkan PP.24 Tahun

1997 dilengkapi dengan Peraturan Jabatan Pembuat Akta Tanah PP.37 Tahun1998), Mandar Maju, Bandung, 1999, hal.18 
Bagir Manan memandang control sebagai "sebuah fungsi sekaligus hak,sehingga lazim disebut sebagai fungsi kontrol atau pengendalian,"5 Dalam pelaksanaan tugas pengawasan tahapan-tahapanpada fungsi manajemen memiliki keterkaitan satu sama lain. Keterpaduanfungsi-fungsi tersebut, memerlukan adanya koordinasi dari fungsi-fungsitersebut dan tuntutan profesi atas kualitas hasil pengawasan menghendaki jugaadanya sistem dan program pengendalian mutu dari proses pelaksanaan tugaspengawasan.

Perencanaan Pengorganisasian Pelaksanaan Pengendalian /pengawasan Koordinasi pengawasan dan jaminan kualitas. Di Indonesia dikenal bermacammacam pengawasan yang secara teoretis dibedakan atas pengawasan langsung dan tidak langsung, pengawasan preventif dan represif, pengawasan internal dan eksternal. Bentuk pengawasan tersebut dapat dijelaskan sebagai berikut: ${ }^{6}$

1. Pengawasan Langsung dan Tidak Langsung

Pengawasan langsung adalah pengawasan yang dilakukan secara pribadi oleh pemimpin atau pengawas dengan mengamati, meneliti, memeriksa, mengecek sendiri secara on the spot di tempat pekerjaan, dan menerimalaporan-laporan secara langsung dari pelaksana.Viktor menambahkan "Hal ini dilakukan dengan inspeksi". Sedangkan pengawasan tidak langsung diadakan dengan mempelajari laporan-laporan yang diterima daripelaksana baik lisan maupun tulisan, mempelajari pendapat masyarakat dansebagainya tanpa on the spot.

2. Pengawasan Preventif dan Represif

Arti pengawasan preventif adalah pengawasan yang bersifat mencegah. Mencegah artinya menjaga jangan sampai suatu kegiatan itu jangan sampai terjerumus pada kesalahan. Pengawasan preventif adalah pengawasan yang bersifat mencegah agar pemerintah daerah tidak mengambil kebijakan yang bertentangan dengan peraturan perundang-undangan yang berlaku. Pengawasan represif adalah pengawasan yang berupa penangguhan atau pembatalan terhadap kebijakan yang telah ditetapkan daerah baik berupa Peraturan Daerah, Peraturan Kepala Daerah, Keputusan DPRD maupun Keputusan Pimpinan DPRD dalam rangka penyelenggaraan pemerintahan daerah. Pengawasan represif berupa penangguhan atau pembatalan terhadap kebijakan daerah yang dinilai bertentangan dengan kepentingan umum,peraturan perundang-undangan yang lebih tinggi dan/atau peraturan perundang-undangan yang lainnya.

3. Pengawasan Internal dan Eksternal

Viktor menjelaskan bahwa: "Pengawasan internal adalah pengawasan yang dilakukan oleh aparatdalam organisasi itu sendiri". ${ }^{7}$ Pengawasan intern lebih dikenal dengan pengawasan fungsional. Pengawasan fungsional adalah pengawasan terhadap pemerintah daerah, yang dilakukan secara fungsional oleh lembaga yang dibentuk untuk melaksanakan pengawasan fungsional, yang kedudukannya merupakan bagian dari lembaga yang diawasi seperti Inspektorat Jenderal,Inspektorat Provinsi, Inspektorat Kabupaten/Kota. Sementara pengawasan eksternal adalah pengawasan yang dilakukan oleh

\footnotetext{
${ }^{5}$ Periksa Bagir Manan, 2000 dalam G. Kartasapoetra, Masalah Pertanahan di Indonesia, Rineka Cipta, Jakarta, 1992 .hlm. 1-2.

${ }^{6}$ Victor M. Situmorang, Aspek Hukum Pengawasan Melekat, PT Rineka Cipta, Jakarta, 1994, hlm.18

${ }^{7}$ Viktor S, Ibid, hal 28.
} 
aparat dari luar organisasi itu sendiri seperti Badan Pemeriksa Keuangan (BPK).

Adapun menurut Sujanto, bahwa: "Pengawasan adalah segala kegiatan untuk mengetahui dan menilai kenyataan yang sebenarnya tentang pelaksanaan tugas dan kegiatan, apakah sesuai dengan yang semestinya atau tidak". ${ }^{\circ}$

Berdasarkan pengertian tersebut dapat diuraikan bila tidak sesuai dengan semestinya atau standar yang berlaku bagi kegiatan yang dilakukan maka telah terjadi penyimpangan.Kesalahan dan penyimpangan dalam pengawasan merupakan kegiatan dari kenyataan yang sebenarnya, selain hal tersebut dalam kegiatan pengawasan juga harus ditemukan sebab-sebab terjadinya penyimpangan, sifat penyimpangan, akibat hukum dari penyimpangan dan kerugian keuangan yang ditimbulkan dari perbuatan penyimpangan serta tindak lanjut hasil pemeriksaan.

Pengawasan dilakukan dengan maksud dan tujuan tidak mencari-cari kesalahan (watchdog) namun untuk :

1. Memastikan bahwa produk atau jasa yang dihasilkan oleh instansi pemerintah memenuhi ketentuan kualitas yang dipersyaratkan atau memenuhi harapan masyarakat (assurance);

2. Memberi bimbingan atau pendampingan kepada manajemen agar kegiatan dapat dilaksanakan sesuai ketentuan dan mencapai sasaran yang diharapkan(consultant);

3. Fasilitator manajemen untuk menggali sendiri kecukupan pengendalian, mengidentifikasi risiko dan mengevaluasi risiko, membuat rencana tindakan dan mendorong untuk proses perbaikan yang berkelanjutan (catalyst). ${ }^{9}$

Monitoring merupakan komponen pengawasan internal terakhir yang diperlukan untuk meyakini apakah seluruh kegiatan yang telah berjalan sesuai dengan prosedur dan ketentuan yang berlaku. Monitoring sangat efektif untuk mencegah praktik-praktik KKN apabila kedua komponen pengawasan di atas telah kuat. Monitoring ini dilaksanakan oleh dua pihak, yaitu:

a. Atasan Langsung

Kegiatan pengawasan oleh atasan langsung ini biasa disebut juga dengan supervisi atau pengawasan melekat. Dalam supervisi dapat terjadi tindakan langsung oleh atasan terhadap bawahan. Fungsi ini melekat pada semua pimpinan di setiap tingkat manajemen.Pengawasan atasan langsung sangat efektif mencegah adanya praktik-praktik KKN apabila atasan langsung tersebut memiliki etika dan integritas yang baik.

b. Badan/ Pengawas Internal sebagai Internal Auditor Pemerintah.

Merupakan Satuan/Badan yang independen dari kegiatan yang diawasi/diaudit namun bertanggungjawab langsung kepada pimpinan pemerintahan. Satuan/Badan pengawas internal ini memiliki fungsi staf yang mempunyai tanggung jawab terbatas yaitu berupa saran/rekomendasi kepada pimpinan suatu instansi, sedangkan keputusan tetap berada pada pimpinan tersebut.

Pimpinan yang memiliki integritas yang tinggi tentu akan melaksanakan apa yang sudah disarankan oleh pengawas internal ini.Internal audit sangat mutlak diperlukan guna membantu manajemen organisasi mengawasi dan melaporkan

${ }^{8}$ Sujanto, 1987, dalam artikel diakses melalui:http//artikel.com.//pada tanggal 10 Nevember 2017.

${ }^{9}$ Edy Sudaryanto, 2 oktober 2012, diakses melalui: http//makalah.hukum.online// tanggal 12 oktober 2017. 
kepada pimpinan organisasi pelaksanaan sistem pengendalian internal, termasuk sistem informasi dan administrasi Dengan demikian pelaksanaan pengawasan internal dalam menjalankan tugas-tugas kepemerintahan dalam rangka mencapai good governance dilingkungan pemerintahan daerah dapat terwujud.

\section{Dasar Hukum Pengawasan Badan Pertanahan Nasional Terhadap PPAT}

Di dalam Pasal 6 ayat (2) Peraturan Pemerintan Nomor 24 Tahun 1997 tentang Pendaftaran Tanah, menetapkan bahwa dalam melaksanakan pendaftaran tanah, Kepala Kantor Pertanahan dibantu oleh PPAT dan Pejabat lain yang ditugaskan untuk melaksanakan kegiatan-kegiatan tertentu menurut Peraturan Pemerintah ini dan peraturan perundang-undangan yang bersangkutan. PPAT dalam membantu pelaksanaan pendaftaran tanah mempunyai tugas pokok seperti yang diatur dalam pasal 2 ayat (1)Peraturan Pemerintah Nomor 37 Tahun 1998, yaitu : melaksanakan sebagian pendaftaran tanah dengan membuat akta sebagai bukti telah dilakukannya perbuatan hukum tertentu mengenai Hak atas tanah atau Hak Milik Atas Satuan Rumah Susun yang akan dijadikan dasar bagi pendaftaran perubahan data pendaftaran tanah yang diakibatkan oleh perbuatan hukum itu. Untuk melaksanakan tugas pokok tersebut di atas, PPAT mempunyai kewenangan membuat akta ottentik mengenai perbuatan hukum tertentu mengenai Hak atas Tanah atau Hak Milik Atas Satuan Rumah Susun.

Adapun Fungsi Badan Pertanahan Nasional dalam hal ini adalah memberikan pembinaan dan pengawasan terhadap PPAT agar dalam melaksanakan jabatannya sesuai dengan peraturan perundang-undangan yang berlaku. Sedangkan peran Ikatan Pejabat Pembuat Akta Tanah (IPPAT) dalam hal ini adalah memberikan bimbingan dan pengawasan terhadap PPAT agar dalam melaksanakan jabatannya sesuai dengan Kode Etik PPAT. Pengawasan yang dilakukan oleh Badan Pertanahan Nasional terhadap PPAT hanyalah bersifat fungsional saja, dalam arti hanya memberikan pembinaan dan pengawasan terhadap PPAT dalam melaksanakan jabatannya. Pengawasan yang dilakukan oleh Ikatan Pejabat Pembuat Akta Tanah hanya terhadap PPAT yang menjadi anggota IPPAT saja dan berimplikasi terhadap pemberian sanksi, dalam arti apabila PPAT tersebut diketahui melakukan pelanggaran terhadap Kode Etik PPAT, maka akan langsung diperiksa dan apabila terbukti melanggar Kode Etik PPAT, maka akan diberikan sanksi sesuai dengan jenis pelanggaran yang dilakukannya.

Peraturan Kepala BPN Nomor 1 Tahun 2006 tentang Ketentuan Pelaksana PP No. 37 Tahun 1998 tentang Peraturan Jabatan Pejabat Pembuat Akta Tanah adalah sebagai pengganti dari Peraturan Menteri Negara Agraria/ Kepala BPN Nomor 4 Tahun 1999 tentang Pelaksanaan PP Nomor 37 Tahun 1998 tentang Peraturan Jabatan Pejabat Pembuat Akta Tanah. Mengenai penunjukan PPAT sementara diatur dalam Pasal 19 Peraturan Kepala BPN Nomor 1 Tahun 2006 sebagaimana telah diubah dengan Peraturan Kepala BPN nomor 23 tahun 2009 tentang Ketentuan Pelaksanaan Peraturan Pemerintah Nomor 37 Tahun 1998, tentang Peraturan Jabatan Pejabat Pembuat Akta Tanah yaitu "Penunjukan Camat sebagai PPAT sementara dilakukan dalam hal di daerah kabupaten/kota sebagai wilayah kerjanya masih tersedia formasi PPAT". Keputusan penunjukan camat sebagai PPAT sementara oleh Kepala Badan yang pelaksanaannnya didelegasikan kepada Kepala Kantor Pertanahan Kabupaten/Kota. 
Mengingat pentingnya tugas dan fungsi Pejabat Pembuat Akta Tanah (PPAT) dalam kehidupan masyarakat di Indonesia sekarang ini maka pemerintah menetapkan juga kriteria-kriteria dan syarat-syarat dari Pejabat Pembuat Akta Tanah.Pengangkatan dan penunjukan Pejabat Pembuat Akta Tanah (PPAT) diatur dalam dalam Pasal 11 dan Pasal 12 Peraturan Kepala Badan Pertanahan Nasional Nomor 1 Tahun 2006 sebagaimana telah diubah dengan Peraturan Kepala BPN nomor 23 tahun 2009.

Agar para PPAT mempunyai wawasan yang luas berkaitan dengan jabatannya sehingga dapat menjalankan tugas dengan baik, maka perlu ada pembinaan dan pengawasan terhadap mereka. Hal itu telah diatur dalam Pasal 65 sampai dengan Pasal 68 Peraturan Kepala Badan Pertanahan Nasional Nomor 1 Tahun 2006, sebagaimana telah diubah dengan Peraturan Kepala BPN nomor 23 tahun 2009 tentang Ketentuan Pelaksanaan Peraturan Pemerintah Nomor 37 Tahun 1998, tentang Peraturan Jabatan Pejabat Pembuat Akta Tanah yakni sebagai berikut:

Pasal 65 menyebutkan bahwa:

1) Pembinaan dan pengawasan terhadap pelaksanaan tugas PPAT dilakukan oleh Kepala Badan.

2) Pembinaan dan pengawasan PPAT sebagaimana dimaksud pada ayat (1) dalam pelaksanaannya oleh kepala Badan, Kepala Kantor Wilayah dan Kepala Kantor Pertanahan.

Pasal 66 menyebutkan bahwa:

1) Pembinaan dan pengawasan terhadap PPAT yang dilakukan oleh Kepala Badan sebagai berikut:

a. Memberikan kebijakan mengenai pelaksanaan tugas jabatan PPAT;

b. Memberikan arahan pada semua pemangku kepentingan yang berkaitan dengan ke-PPAT-an;

c. Melakukan, pembinaan dan pengawasan atas organisasi profesi PPAT agar tetap berjalan sesuai dengan arah dan tujuannya;

d. Menjalankan tindakan-tindakan lain yang dianggap perlu untuk memastikan pelayanan PPAT tetap berjalan sebagaimana mestinya;

e. Melakukan pemninaan dan pengawasan terhadap PPAT dan PPAT Sementara dalam rangka menjalankan kode etik profesi PPAT.

2) Pembinaan dan pengawasan terhadap PPAT yang dilakukan oleh Kepala Kantor sebagai berikut:

a. Menyampaikan dan menjelaskan kebijakan dan peraturan pensertipikatan tanah serta petunjuk teknis pelaksanaan tugas PPAT yang telah ditetapkan oleh Kepala Badan dan peraturan perundangundangan yang berlaku;

b. Membantu melakukan sosialisasi, diseminasi kebijakan dan peraturan pensertipikatan tanah serta petunjuk teknis;

c. Secara periodik melakukan pengawasan Kantor PPAT guna memastikan ketertiban administrasi, pelaksanaan tugas dan kewajiban sesuai dengan ketentuan peraturan perundang-undangan ke-PPAT-an.

3) Pembinaan dan pengawasan terhadap PPAT yang dilakukan oleh Kepala Kantor Pertanahan sebagai berikut:

a. Membantu menyampaikan dan menjelaskan kebijakan dan peraturan pensertipikatan tanah serta petunjuk teknis pelaksanaan tugas PPAT 
yang telah ditetapkan oleh Kepala Badan dan peraturan perundangundangan;

b. Memeriksa akta yang dibuat PPAT dan memberitahukan secara tertulis kepada PPAT yang bersangkutan apabila ditemukan akta yang tidak memenuhi syarat untuk digunakan sebagai dasar pendaftaran haknya;

c. Melakukan pemeriksaan mengenai pelaksanaan kewajiban operasional PPAT.

Sedangkan berdasarkan Pasal 7 Kode Etik IPPAT menyebutkan bahwa pengawasan atas pelaksanaan kode etik ini dilakukan dengan cara sebagai berikut:

1. Pada tingkat pertama oleh Pengurus Daerah IPPAT dan Majelis Kehormatan Daerah bersama-sama dengan pengurus cabang dan seluruh anggota;

2. Pada tingkat terakhir oleh Pengurus Pusat IPPAT dan Majelis Kehormatan Pusat.

Pasal 6 ayat (1) Kode Etik IPPAT menjelaskan bahwa sanksi yang dikenakan terhadap anggota yang melakukan pelanggaran kode etik dapat berupa : teguran, peringatan, schorsing (pemecatan sementara dari keanggotaan IPPAT, Onzetting (pemecatan dari keanggotaan IPPAT), pemberhentian dengan tidak hormat dari keanggotaan IPPAT. Pasal 6 ayat (2) menjelaskan penjatuhan sanksisanksi sebagaimana terurai diatas terhadap anggota yang melakukan pelanggaran kode etik disesuaikan dengan kuantitias dan kualitas pelanggaran yang dilakukan anggota tersebut. Sedangkan Perihal sanksi hukum terhadap PPAT lebih tegas digambarkan dalam Pasal 28 Ayat (1) huruf c Peraturan Kepala Badan Pertanahan Nasional Nomor 1 Tahun 2006, sebagaimana telah diubah dengan Peraturan Kepala BPN nomor 23 tahun 2009 tentang Ketentuan Pelaksanaan Peraturan Pemerintah Nomor 37 Tahun 1998, tentang Peraturan Jabatan Pejabat Pembuat Akta Tanah bahwa PPAT diberhentikan dengan hormat dari jabatannya karena melakukan pelanggaran ringan terhadap larangan atau kewajiban sebagai PPAT. Kemudian Pasal 28 Ayat (2)menyebutkan bahwa PPAT diberhentikan dengan tidak hormat dari jabatannya karena: (a) melakukan pelanggaran berat terhadap larangan atau kewajiban sebagai PPAT; (b) dijatuhi hukuman kurungan penjara karena melakukan kejahatan perbuatan pidana yang diancam dengan hukuman kurungan atau penjara selama-lamanya 5 (lima) tahun atau lebih berat berdasarkan putusan pengadilan yang sudah memperoleh kekuatan hukum tetap; dan (c) melanggar Kode Etik Profesi.

\section{PEMBAHASAN}

\section{Fungsi Badan Pertanahan Nasional Dalam Pengawasan Pejabat Pembuat Akta Tanah Di Wilayah Tanjung Jabung Barat}

Di dalam Pasal 6 ayat (2) Peraturan Pemerintan Nomor 24 Tahun 1997 tentang Pendaftaran Tanah, menetapkan bahwa dalam melaksanakan pendaftaran tanah, Kepala Kantor Pertanahan dibantu oleh PPAT dan Pejabat lain yang ditugaskan untuk melaksanakan kegiatan-kegiatan tertentu menurut Peraturan Pemerintah ini dan peraturan perundang-undangan yang bersangkutan. PPAT dalam membantu pelaksanaan pendaftaran tanah mempunyai tugas pokok seperti yang diatur dalam pasal 2 ayat (1) Peraturan Pemerintah Nomor 37 Tahun 1998, yaitu : melaksanakan sebagian pendaftaran tanah dengan membuat akta sebagai bukti telah dilakukannya perbuatan hukum tertentu mengenai Hak atas tanah atau Hak Milik Atas Satuan Rumah Susun yang akan dijadikan dasar bagi pendaftaran 
perubahan data pendaftaran tanah yang diakibatkan oleh perbuatan hukum itu. Untuk melaksanakan tugas pokok tersebut di atas, PPAT mempunyai kewenangan membuat akta ottentik mengenai perbuatan hukum tertentu mengenai Hak atas Tanah atau Hak Milik Atas Satuan Rumah Susun.

Oleh karena itu, agar PPAT dalam melaksanakan jabatannya mempunyai tanggung jawab yang besar kepada masyarakat, maka diperlukan suatu tindakan pengawasan terhadap PPAT tersebut, agar dalam melaksanakan jabatannya sesuai dengan peraturan perundang-undangan yang berlaku dan Kode Etik PPAT. Masalah pengawasan terhadap PPAT dalam melaksanakan jabatannya. PihakPihak yang berwenang melakukan pengawasan terhadap PPAT dalam melaksanakan jabatannya adalah Badan Pertanahan Nasional dan Ikatan Pejabat Pembuat Akta Tanah (IPPAT).

Sebagaimana yang dijilaskan oleh kepala BPN Tanjung Jabung Barat Bpk. Nurman Antoni bahwa:

Fungsi Badan Pertanahan Nasional dalam hal ini adalah memberikan pembinaan dan pengawasan terhadap PPAT agar dalam melaksanakan jabatannya sesuai dengan peraturan perundang-undangan yang berlaku. Sedangkan Fungsi IPPAT dalam hal ini adalah memberikan bimbingan dan pengawasan terhadap PPAT agar dalam melaksanakan jabatannya sesuai dengan Kode Etik PPAT. Pengawasan yang dilakukan oleh Badan Pertanahan Nasional terhadap PPAT hanyalah bersifat fungsional saja, dalam arti hanya memberikan pembinaan dan pengawasan terhadap PPAT dalam melaksanakan jabatannya. Pengawasan yang dilakukan oleh Ikatan Pejabat Pembuat Akta Tanah hanya terhadap PPAT yang menjadi anggota IPPAT saja dan berimplikasi terhadap pemberian sanksi, dalam arti apabila PPAT tersebut diketahui melakukan pelanggaran terhadap Kode Etik PPAT, maka akan langsung diperiksa dan apabila terbukti melanggar Kode Etik PPAT, maka akan diberikan sanksi sesuai denganjenis pelanggaran yang dilakukannya. ${ }^{10}$

Agar para PPAT mempunyai wawasan yang luas berkaitan dengan jabatannya sehingga dapat menjalankan tugas dengan baik, maka perlu ada pembinaan dan pengawasan terhadap mereka. Hal itu telah diatur dalam Pasal 65 sampai dengan Pasal 68 Peraturan Kepala Badan Pertanahan Nasional Nomor 1 Tahun 2006, sebagaimana telah diubah dengan Peraturan Kepala BPN nomor 23 tahun 2009 tentang Ketentuan Pelaksanaan Peraturan Pemerintah Nomor 37 Tahun 1998, tentang Peraturan Jabatan Pejabat Pembuat Akta Tanah

Lebih lanjut diuaraikan pula oleh Bpk. Rosyidin selaku Pejabat Pembinaan dan Pengawasan bahwa:

Sejalan dengan Peraturan BPN maka yang telah dilaksanakan dalam rangka pembinaan dan pengawasan terhadap PPAT, adapun yang telah dan terus diupayakan oleh kami disini adalah mencakup hal-hal sebagai berikut:

1. Memberikan kebijakan mengenai pelaksanaan tugas jabatan PPAT;

2. Memberikan arahan pada semua pemangku kepentingan yang berkaitan dengan ke-PPAT-an;

3. Melakukan, pembinaan dan pengawasan atas organisasi profesi PPAT agar tetap berjalan sesuai dengan arah dan tujuannya;

${ }^{10}$ Nurman Antoni, Wawancara Kepala Kantor Pertanahan Tanjung Jabung Barat, pada tgl. 19 Desember 2017 
4. Menjalankan tindakan-tindakan lain yang dianggap perlu untuk memastikan pelayanan PPAT tetap berjalan sebagaimana mestinya;

5. Melakukan pemninaan dan pengawasan terhadap PPAT dan PPAT Sementara dalam rangka menjalankan kode etik profesi PPAT. ${ }^{11}$

Ditambahkan pula oleh beliau bahwa:

Pembinaan dan pengawasan terhadap PPAT yang dilakukan oleh Kepala Kantor sebagai berikut:

Ada beberapa kegiatan yang dilaksanakan dalam rangka pembinaan dan pengawasan ini. Yakni : menyampaikan dan menjelaskan kebijakan dan peraturan pensertipikatan tanah serta petunjuk teknis pelaksanaan tugas PPAT yang telah ditetapkan oleh Kepala Badan dan peraturan perundang-undangan yang berlaku; membantu melakukan sosialisasi, diseminasi kebijakan dan peraturan pensertipikatan tanah serta petunjuk teknis; dan berupaya melakukan kegiatan secara periodik melakukan pengawasan Kantor PPAT guna memastikan ketertiban administrasi, pelaksanaan tugas dan kewajiban sesuai dengan ketentuan peraturan perundang-undangan. ${ }^{12}$

Senada dengan yang dijelaskan oleh bapak Nurman Antoni, Kepala Badan Pertanahan Tanjung Jabung Barat bahwa:

"dalam melakukan Pembinaan dan pengawasan terhadap PPAT, oleh karena fungsi ini melekat pada tupoksi kami secara intern terhadap PPAT, dimana PPAT ini merupakan pejabat yang memang secara organisasi terkait erat dengan kantor pertanahan, maka yang dilakukan adalah sebagai berikut:

1. Membantu menyampaikan dan menjelaskan kebijakan dan peraturan pensertipikatan tanah serta petunjuk teknis pelaksanaan tugas PPAT

2. Melakuakan pemeriksaan akta yang dibuat PPAT dan memberitahukan secara tertulis kepada PPAT yang bersangkutan apabila ditemukan akta yang tidak memenuhi syarat untuk digunakan sebagai dasar pendaftaran haknya;

3. Terus sedapat mungkin melakukan pemeriksaan mengenai pelaksanaan kewajiban operasional PPAT. ${ }^{\mathbf{1 3}}$

Kemudian dijelaskan pula oleh beliau bahwa:

"Berdasarkan Pasal 53 ayat (2) Peraturan Kepala BPN No. 1 Tahun 2006 tentang Ketentuan Pelaksanaan PP No. 37 Tahun 1998 tentang Peraturan Jabatan Pejabat Pembuat Akta Tanah ("Perka BPN 1/2006") sebagaimana telah diubah dengan Peraturan Kepala BPN No. 23 Tahun 2009 tentang Perubahan Atas Peraturan Kepala BPN No. 1 Tahun 2006 tentang Ketentuan Pelaksanaan PP No. 37 Tahun 1998 tentang Peraturan Jabatan Pejabat Pembuat Akta Tanah disebutkan bahwa Pengisian blanko akta dalam rangka pembuatan akta PPAT harus dilakukan sesuai dengan kejadian, status dan data yang benar serta didukung dengan dokumen sesuaiperaturan perundang-undangan.Bagi setiap PPAT berlaku pula Kode Etik PPAT yang mengatur mengenai larangan dan kewajiban bagi PPAT. Salah satu kewajiban PPAT adalah bekerja dengan penuh rasa tanggung jawab, mandiri, jujur dan tidak berpihak (Pasal 3 huruf e Kode Etik PPAT). Dengan demikian, pembuatan Akta Jual Beli (AJB) yang

${ }^{11}$ Rosyidin, Wawancara Pejabat Pembinaan Dan Pengawasan Pertanahan Tanjung Jabung Barat, pada tgl. 29 Desember 2017

12 Rosyidin, Wawancara Pejabat Pembinaan Dan Pengawasan Pertanahan Tanjung Jabung Barat, pada tgl. 29 Desember 2017

${ }^{13}$ Nurman Antoni, Wawancara Kepala Kantor Pertanahan Tanjung Jabung Barat, pada tgl. 19 Desember 2017 
tidak sesuai dengan harga transaksi yang sebenarnya telah melanggar Perka BPN 1/2006 dan Kode Etik PPAT karena ketidakbenaran data yang ditulis dalam akta."14

Dari pendapat diatas, penulis menyimpulkan bahwa: terkait dengan pembinaan dan pengawasan ini, Kantor Pertanahan Tanjung Jabung Barat merupakan rekan kerja yang secara struktur organisasi merupakan lembaga pemerintah yang melakukan pengawasan dan pembinaan mengingat PPAT adalah pejabat yang berwenang membuat akta tanah sebelum sertifikan dikeluarkan,. Kantor Pertanahan Tanjung Jabung Barat khususnya telah berupaya melakukan pengawasan terhadap PPAT sejalan dengan peraturan yang berlaku, karena Badan Pertanahan merupakan badan yang bertanggung jawab langsung atas pelanggaran yang dilakukan PPAT, dan pengawasan ini lebih bersifat fungsional, dimana telah diatur dalam pasal 56, 57 Perka BPN Nomor 1 Tahun 2006 sebagaimana telah diubah dengan Peraturan Kepala BPN No. 23 Tahun 2009 tentang Perubahan Atas Peraturan Kepala BPN No. 1 Tahun 2006 tentang Ketentuan Pelaksanaan PP No. 37 Tahun 1998 tentang Peraturan Jabatan Pejabat Pembuat Akta Tanah.

Merujuk pada pendapat Viktor Situmorang pada uraian sebelumnya, bahwa dari berbagai jenis pengawasan maka menurut penulis pengawasan dan pembinaan yang dilakukan oleh kantor pertanahan ini merupakan jenis pengawasan yang bersifat intern. Dimana antara fungsinya terhadap fungsi PPAT memiliki tupoksi yang hierraki, oleh karena PPAT merupakan pejabat yang akan meneruskan tugasnya ke kantor pertanahan untuk penerbitan sertifikat dari akta yang telah dibuatnya.

Selanjutnya terhadap sanksi apa yang akan diterapkan, Pasal 55 Perka BPN Nomor 1 Tahun 2006 sebagaimana telah diubah dengan Peraturan Kepala BPN nomor 23 tahun 2009 tentang Ketentuan Pelaksanaan Peraturan Pemerintah Nomor 37 Tahun 1998, tentang Peraturan Jabatan Pejabat Pembuat Akta Tanah mengatur bahwa PPAT bertanggung jawab secara pribadi atas pelaksanaan tugas dan jabatannya dalam setiap pembuatan akta.

Atas pelanggaran yang dilakukan oleh PPAT, dalam Pasal 28 Perka BPN $23 / 2009$, diatur mengenai pemberhentian, pelanggaran ringan, serta pelanggaran berat yang dilarang dilakukan oleh seorang PPAT.

Adapun uraian dari ketentuan hukum atas sanksi yang berlaku dapat dilihat pada aturan berikut:

\section{Pasal 28}

(1) PPAT diberhentikan dengan hormat dari jabatannya oleh Kepala Badan karena:

a. permintaan sendiri;

b. tidak lagi mampu menjalankan tugas karena keadaan kesehatan badan atau kesehatan jiwanya, setelah dinyatakan oleh tim pemeriksa kesehatan berwenang atas permintaan Kepala Badan atau pejabat yang ditunjuk;

c. melakukan pelanggaran ringan terhadap larangan atau kewajiban sebagai PPAT;

d. diangkat sebagai PNS atau anggota TNI/POLRI.

(2) PPAT diberhentikan dengan tidak hormat dari jabatannya oleh Kepala Badan, karena:

${ }^{14}$ Nurman Antoni, Wawancara Kepala Kantor Pertanahan Tanjung Jabung Barat, pada tgl. 19 Desember 2017 
a. melakukan pelanggaran berat terhadap larangan atau kewajiban sebagai PPAT;

b. dijatuhi hukuman kurungan/penjara karena melakukan kejahatan perbuatan pidana yang diancam hukuman kurungan atau penjara paling lama 5 (lima) tahun atau lebih berat berdasarkan putusan pengadilan yang sudah mempunyai kekuatan hukum tetap;

c. melanggar kode etik profesi.

(3) Pelanggaran ringan sebagaimana dimaksud pada ayat (1) huruf c antara lain:

a. memungut uang jasa melebihi ketentuan peraturan perundang-undangan;

b. dalam waktu 2 (dua) bulan setelah berakhirnya cuti tidak melaksanakan tugasnya kembali sebagaimana dimaksud dalam Pasal 42 ayat (5);

c. tidak menyampaikan laporan bulanan mengenai akta yang dibuatnya sebagaimana dimaksud dalam Pasal 62;

d. merangkap jabatan sebagaimana dimaksud dalam Pasal 30 ayat (1); dan

e. lain-lain yang ditetapkan oleh Kepala Badan.

(4) Pelanggaran berat sebagaimana dimaksud pada ayat (2) huruf a, antara lain:

a. membantu melakukan permufakatan jahat yang mengakibatkan sengketa atau konflik pertanahan;

b. melakukan pembuatan akta sebagai permufakatan jahat yang mengakibatkan sengketa atau konflik pertanahan;

c. melakukan pembuatan akta di luar daerah kerjanya kecuali yang dimaksud dalam Pasal 4 dan Pasal 6 ayat (3);

d. memberikan keterangan yang tidak benar di dalam akta yang mengakibatkan sengketa atau konflik pertanahan;

e. membuka kantor cabang atau perwakilan atau bentuk lainnya yang terletak di luar dan atau di dalam daerah kerjanya sebagaimana dimaksud dalam Pasal 46;

f. melanggar sumpah jabatan sebagai PPAT;

g. pembuatan akta PPAT yang dilakukan, sedangkan diketahui oleh PPAT yang bersangkutan bahwa para pihak yang berwenang melakukan perbuatan hukum atau kuasanya sesuai peraturan perundang-undangan tidak hadir dihadapannya;

h. pembuatan akta mengenai hak atas tanah atau Hak Milik Atas Satuan Rumah Susun yang oleh PPAT yang bersangkutan diketahui masih dalam sengketa yang mengakibatkan penghadap yang bersangkutan tidak berhak melakukan untuk perbuatan hukum yang dibuktikan dengan akta;

i. PPAT tidak membacakan aktanya dihadapan para pihak maupun pihak yang belum atau tidak berwenang melakukan perbuatan sesuai akta yang dibuatnya;

j. PPAT membuat akta dihadapan para pihak yang tidak berwenang melakukan perbuatan hukum sesuai akta yang dibuatnya;

k. PPAT membuat akta dalam masa dikenakan sanksi pemberhentian sementara atau dalam keadaan cuti;

1. lain-lain yang ditetapkan oleh Kepala Badan.

Pasal 29

(1) Pemberhentian PPAT sebagaimana dimaksud dalam Pasal 28 ditetapkan oleh Kepala Badan berdasarkan usulan Kepala Kantor Pertanahan melalui Kepala Kantor Wilayah. 
(2) Pemberhentian sementara PPAT sebagaimana dimaksud dalam Pasal 11 Peraturan Pemerintah Nomor 37 Tahun 1998 ditetapkan oleh Kepala Badan berdasarkan usulan Kepala Kantor Pertanahan melalui Kepala Kantor Wilayah.

Selanjutkan Menurut Dorika, SH selaku PPAT, menjelaskan bahwa:

"berdasarkan pada Perka BPN 1/2006 pemberian keterangan yang tidak benar dalam akta adalah termasuk pelanggaran berat oleh PPAT yang dapat dikenakan sanksi pemberhentian dengan tidak hormat dari jabatannya oleh Kepala Badan Pertanahaan Nasional Indonesia". ${ }^{15}$

Dijelaskan pula oleh bapak Rasyidin selaku pejabat Ppengawasan dan pembinaan PPAT bahwa:

Mengenai sanksi yang dapat dikenakan terhadap PPAT juga ditetapkan dalam Pasal 6 ayat (1) Kode Etik PPAT yakni bagi anggota yang melakukan pelanggaran Kode Etik dapat dikenai sanksi berupa:
a. Teguran;
b. Peringatan;
c. Schorsing (pemecatan sementara) dari keanggotaan IPPAT;
d. Onzetting (pemecatan) dari keanggotaan IPPAT;
e. Pemberhentian dengan tidak hormat dari keanggotaan IPPAT.

Penjatuhan sanksi-sanksi tersebut disesuaikan dengan kuantitas dan kualitas pelanggaran yang dilakukan anggota tersebut"16

Kemudian dijelaskan oleh Irzan Hutagalung, SH, PPAT Wilayah Tanjung Jabung Barat bahwa:

Sebagai PPAT, kami selalu diundang untuk ikut dalam kegiatan pembinaan yang dilakukan oleh Kantor Pertanahan bekerjasama dengan IPPAT, dalam pertemuan tersebut selalu diberikan data PPAT yang telah melakukan pelanggaran dan sanksi yang telah diterapkan, dan sepertinya dua tahun terahir ini yakni 2016 ada satu pelanggaran yang diberi sanksi teguran dan peringatan tertulis atas kesalahannya, dan Tahun 2017 yang imelakukan pelanggaran hanya sebatas pelanggaran ketertiban administrasi, artinya kami sebagai PPAT sangat serius dan berhati-hati dalam melaksanakan tugas kami. ${ }^{17}$

Selanjutnya dapat disimpulkan bahwa kegiatan pembinaan dan pengawasan ini merupakan sarana penting dan efektif dalam mengatasi tindakan PPAT yang terkadang kurang teliti, apalagi terhadap beberapa tanah yang masih dalam persengketaan. Kantor pertanahan merupakan yang berwenang melaksanakan kegiatan ini, dan untuk pelanggaran ataupun sanksi yang diterapkan kantor pertanahan juga bekerja sama dengan Ikatan Pejabat Pembuat Akta Tanah dan dewan kehormatan kode etik PPAT. Hal ini menunjukan bahwa prinsip kehati-hatian sangat penting ditaati oleh PPAT dalam kinerja yang dilakukannya, mengingat telah dirumuskannya aturan berupa Peraturan Kepala Badan

${ }^{15}$ Dorika, wawancara Pejabat Pembuat Akta Tanah Tanjung Jabung Barat, pada tgl. 03 Januari 2018

${ }^{16}$ Rasyidin, wawancara pejabat Pengawasan dan pembinaan PPAT, pada tgl. 29 desember 2017

${ }^{17}$ Irzan Hutagalung, Pejabat Pembuat Akta Tanah Tanjung Jabung Barat, pada tgl. 03 Januari 2018 
Pertanahan Nasional Nomor 23 Tahun 2009, secara rinci telang mengatur jenis pelanggaran beserta sanksinya, untuk dijadikan pedoman kinerja baik bagi kantor pertanhan maupun PPAT. Hal ini sejalan dengan pendapat Sri Soemantri bahwa "dalam menjalankan fungsi dan kewajibannya pemerintah harus selalu berpijak pada peraturan perundang-undangan yang berlaku"18

Instrumen hukum dalam pelaksanaan fungsi kantor pertanahan khususnya Tanjung Jabung Barat berpedoman pada Perka BPN Nomor 23 Tahun 2009, Dimana BPN merupakan Badan yang dibentuk pemerintah dalam rangka melaksanakan fungsi pembinaan dan pengawasan terhadap kinerja Pejabat Pembuat Akta Tanah. Fungsi ini dilakukan dengan sifat fungsional dan merupakan jenis fungsi intern, mengingat PPAT dan Badan Pertanahan secara fungsional memiliki kinerja yang hierarki. Adapaun selain Badan Pertanahan juga melibatkan Ikatan Pejabat Pembuat Akta Tanah beserta dewan kehormatan kode etik PPAT.

\section{SIMPULAN}

Disimpulkan bahwa instrumen hukum dalam pelaksanaan fungsi kantor pertanahan khususnya Tanjung Jabung Barat berpedoman pada Perka BPN Nomor 23 Tahun 2009, Dimana BPN merupakan Badan yang dibentuk pemerintah dalam rangka melaksanakan fungsi pembinaan dan pengawasan terhadap kinerja Pejabat Pembuat Akta Tanah. Fungsi ini dilakukan dengan sifat fungsional dan merupakan jenis fungsi intern, mengingat PPAT dan Badan Pertanahan secara fungsional memiliki kinerja yang hierarki. Adapaun selain Badan Pertanahan juga melibatkan Ikatan Pejabat Pembuat Akta Tanah beserta dewan kehormatan kode etik PPAT.

\section{DAFTAR PUSTAKA}

A.P. Parlindungan, Pendaftaran Tanah di Indonesia (Berdasarkan PP.24 Tahun 1997 dilengkapi dengan Peraturan Jabatan Pembuat Akta Tanah PP.37 Tahun1998), Bandung, Mandar Maju. 1999.

Bagir Manan, 2000 dalam G. Kartasapoetra, Masalah Pertanahan di Indonesia, Jakarta, Rineka Cipta, 1992

Irfan Fachruddin, Pengawasan Peradilan Administrasi Terhadap Tindakan Pemerintah, Bandung, Alumni, 2004.

Sri Soemantri, Bunga Rampai Hukum Tata Negara, Bandung, Alumni, 1992.

Victor M. Situmorang, Aspek Hukum Pengawasan Melekat, Jakarta: PT Rineka Cipta, 1994.

Sujanto, 1987, dalam artikel diakses melalui:http//artikel.com.//pada tanggal 10 November 2017.

Edy Sudaryanto, 2 oktober 2012, diakses melalui: http//makalah.hukum.online// tanggal 12 oktober 2017.

Peraturan Kepala Badan Pertanahan Nasional Nomor 1 Tahun 2006 sebagaimana telah diubah dengan Peraturan Kepala BPN No. 23 Tahun 2009 tentang Perubahan Atas Peraturan Kepala BPN No. 1 Tahun 2006 tentang

\footnotetext{
${ }^{18}$ Sri Soemantri, Bunga Rampai Hukum Tata Negara Indonesia, Alumni, Bandung 1992, hal. 29 
Ketentuan Pelaksanaan PP No. 37 Tahun 1998 tentang Peraturan Jabatan Pejabat Pembuat Akta Tanah .

Undang-Undang Nomor. 5 Tahun 1960 Tentang. Peraturan Dasar PokokPokok Agraria 